\title{
Working Capital Management on Profitability and Earning Assets of Insurance Industry in Egypt
}

\author{
Salah Mohamed Eladly ${ }^{1}$ \\ ${ }^{1}$ Higher Institute of Advanced Studies, Giza, Egypt \\ Correspondence: Salah Mohamed Eladly, Higher Institute of Advanced Studies, Giza, Egypt. E-mail: \\ salah_phd@yahoo.com
}

Received: July 30, 2021

Accepted: September 12, 2021

Online Published: November 12, 2021

doi:10.5539/ijbm.v16n12p17

URL: https://doi.org/10.5539/ijbm.v16n12p17

\begin{abstract}
This paper is an attempt to investigate the effect of working capital management, measured by (Current Ratio, Quick Ratio and Liquidity)on dependent variables (Return on Assets, Return on Equity and Earning Assets (Asset Quality) of insurance firms in Egypt, the study sample is 49\% from total insurance firms working of the insurance market in Egypt in 1999- 2019.A structural equation modelling was selected to construct of the model of this study, The evidences show that There is a positive significant effect on construct of the independent variables, current ratio $\left(\mathrm{x}_{1}\right)$, quick ratio $\left(\mathrm{x}_{2}\right)$, and liquidity $\left(\mathrm{x}_{3}\right)$ on construct of the dependent variables in terms of Return on Equity $\left(\mathrm{Y}_{1}\right)$, at a probability level less than $(0.001)$. This validates the first hypothesis; the independent variables Current Ratio $\left(\mathrm{x}_{1}\right)$, Quick Ratio $\left(\mathrm{x}_{2}\right)$, and Liquidity $\left(\mathrm{x}_{3}\right)$ have a significant effect on the dependent variables Return on Equity $\left(\mathrm{Y}_{1}\right)$, There is a positive significant effect on the construct of the independent variables, Current Ratio $\left(\mathrm{x}_{1}\right)$, Quick Ratio $\left(\mathrm{x}_{2}\right)$, and Liquidity $\left(\mathrm{x}_{3}\right)$ on the construct of the dependent variables in terms of Earning Assets (Asset Quality) $\left(\mathrm{Y}_{3}\right)$, probability level less than (0.001). This validates of the third hypothesis; the independent variables in terms of Current Ratio $\left(\mathrm{x}_{1}\right)$, Quick Ratio $\left(\mathrm{x}_{2}\right)$, and Liquidity $\left(\mathrm{x}_{3}\right)$ have a significant effect on (Earning Assets) Asset Quality $\left(\mathrm{Y}_{3}\right)$.
\end{abstract}

Keywords: structural equation modelling, working capital, return on equity, return on assets, (earning assets) asset quality

\section{Introduction}

The insurance companies are heavily regulated in Egypt like elsewhere in terms of their portfolio and liquidity constraints which appear in ratios by the Financial Regulatory Authority in Egypt, especially most of these elements represent the working capital management. Treasury bills and government, securities which represent $10 \%$ of paid capital for each one of them. So, this study sought to identify the relationship between working capital management measured by (Current Ratio, Quick Ratio and Liquidity) on Profitability measured by (Return on Equity and Return on Assets) and Asset Quality

\section{Literature review}

Sonia B. caballero \& et al 2010 the study exposed negative relationship between fixed assets, return on assets on cash conversion cycle also there is no effect onthe Size of the firm on cash conversion cycle, whereas there is relationship between economic variable (interest rate and GDP) on Cash Conversion Cycle. Pedro G Teruel and Pedro M, Salono (2007) they have focused on investigate relationship between ROA and working capital management, they found a negative relationship between return on asset on account receivables turnover, inventories turnover, payables deferral period and cash conversion cycle whereas there is positively relationship between size of the firms on cash conversion cycle. Elangkumaran and Nimalathasan (2016) the study exposed is significant relationship between cash conversion cycle, inventories turnover and debtors deferral period on profitability which measured by (return on assets). But debtors deferral period has a negatively relationship on profitability. Mihir Dash and Rani Hanuman (2000) this study presented a suggested goal programming model, the results show that highly positive sensitive to change in account receivable, marketable securities fixed asset and cash respectively but negative sensitive to change in current liability. H Jamal Zuhiari (2011) the researchers investigated relationship between financial leverage on profitability they found a positive significant relationship between financial leverage on profitability whereas there is a negative significant relationship between operating leverage on profitability also there is a positive relationship between growth on profitability with size of the 
firms in Pakistan. Andre Luiz and Valcemiro Nossa (2010), the study analysis concluded that different working capital financing structure has a relationship on different levels of profitability, solvency and liquidity of insurance in Brazilian insurance market. Daisuke Tsuruta (2018) this study found a negative relationship between working capital on firm's performance over the short term, however there is positive relationship between working capital on firms' performance over long term. Also there is a positive relationship between working capital on default risk and sales growth. Sara Fernandez-Lopez et al (2020) to examine relationship between dependent variables and independent variables the study used dynamic panel data analysis, the study found a negative significant relationship between working capital management measured by (sales turnover, inventories turnover, payable deferral period, cash conversion cycle and financial leverage) on firms profitability in Spain cheese industry over the period 2010- 2016. Senthilmani Thuvarakan (2013), the study found a negative relationship between working capital measured by (receivable period, payable deferral period, inventories turnover and cash conversion cycle) on profitability. Whereas there is a positive relationship between sales on profitability in Telecommunication Sector, however Construction Sector there is insignificant relationship between working capital on profitability. Robert Kieschnick et al (2013), the study found a significant relationship value of additional dollar invested in net operating working on future sales expectation. Julius Enqvist et al. (2013), the study found a negative relationship between cash conversion cycle on firm profitability also working capital management effect on profitability. Mansoori and Muhammad (2012), the study found a negative significant relationship between debt ratios on profitability, whereas there is a positive relationship between working capital management on profitability, also there is statically positive relationship between cash conversion cycle on return on investment. Rathiranee Yogendrarajah and Sankeetha Thanabalasingam (2014), the study found negatively relationship between return on assets on inventory turnover and cash conversion cycle. Also there is an inverse significant associated with working capital management on financial performance. Nadeem Iqbal et al. (2014), the finding indicates that there is a negative significant relationship between net operating profitability on cash conversion cycle, average payment period, inventory turnover and average collection period. Muhammad S. Sial and Aqsa Chaudhry (2012), the study found a negative relationship between working capital management on profitability. Also found a negative significant relationship between size of the firm and debt ratio on profitability. Mathew D. Hill et al. (2010), the paper results show that there is a negative relationship between working capital ratio on sales volatility, market to book ratio, whereas found statistically positive relationship between working capital requirements on gross operating cash flow as well as firm size but non statistically relationship between working capital requirements on gross profit margin. Ashok K. Panigrahi (2014) the study found a positive relationship between working capital management measured by (cash conversion cycle, collection days and current assets ratio) on profitability and liquidity... Iluta Arbidane and Svetlana Ignatjeva (2012), the study found a statistically difference relationship between inventory turnover, payable deferral period, size of the companies and debt ratio on gross operating profitability and return on assets. Also found a negative significant relationship between the current ratio on return on assets. Sugeewa Kadithuwakka (2015), the study found a negative relationship between inventory turnover, cash conversion cycle and debtor's deferral period on profitability in Sri lank manufacturing sector but found a positive relationship between creditors conversion cycle on profitability. also found a significant effect of financial leverage, firm size and sales growth on profitability. Samuel Kwaku Agyei and Benjamin Yeboah (2011), the findings indicate that there is a significant positive relationship between cash conversion cycle on profitability in Ghana Banking Sector. Also firm size, credit risk and exchange risk capital structure affected on profitability. While, that there is a significantly opposite relationship between creditors payment period on profitability. Thomas Korankye and Rosca S. Adarquah (2013) the study found a negative relationship between payables deferral period, payment period, account receivables collection period and inventory turnover period on profitability however there is a negative significant relationship leverage on profitability, whereas there is a positively significant relationship between current assets ratio on profitability. Vinay Kandpal (2015) the results indicate that there is a negative relationship between $t$ current ratio, debaters turnover and quick ration on return on investment whereas found a positive relationship between return on investment on creditors turnover. Ratnam Vijayakumaran and Sunitha Vijayakumaran (2017), this study revealed that there is a positive relationship between working capital management and corporate performance in Sri Lankan manufacturing firms, however there is a negative relationship between cash conversion cycle on return on assets. Ratnam Vijayakumaran (2019) finding indicates that there is anegative relationship between the net trade cycle, inventories and the number of days account receivable on the Chinese Firms. Haitham Nobanee \& Ayman E. Haddad (2014) the study found significant negative between cash conversion cycle, receivables turnover, and inventory turnover on profitability, but there is a positive significant relationship between payables deferral period on profitability of Japanese firms. Yuli Anwar (2018), the study found a significant effect of cash conversion cycle and inventory turnover, collection 
period on ROI on Manufacturing Sector in Indonesia. Hingurala Arachchi et al. (2017), the study found a negative significant relationship between cash conversion cycle, account receivables and inventory days on value of the firm, but there is a positive significant relationship between account payables on value of the firm measured by Tobin Q ratio., Amr A Moussa(2018 ) the study exposed a positive relationship between firm performance on cash conversion size, growth opportunity firm age and economic condition, however firm performance has a negative relationship on firm size and level of debt. Jakpar et al. (2017), the estimation findings indicate that there is a negative significant relationship between cash conversion cycle and debt ratio on return on assets whereas there is a positive significant relationship between leverage collective period, inventory turnover period and firm size on return on assets in Malaysian Manufacturing sector, Amarjit Gill et al. (2010), The estimation findings that there is a negative significant relationship between cash conversion cycle, debt ratio on profitability but there is a positive significant relationship between average collective period inventory turnover period on profitability but insignificant relationship between firm size on profitability in United States firms. Muhammad Azeem Naz et al. (2021), they investigated the relationship between corporate governance, working capital management and firm performance, the result of multivariate analysis to test the mediation of working capital management measured by cash conversion cycle, capital ratio and cash conversion efficiency have positive relationship with firm performance of non-financial firms listed in Pakistan stock exchange.

\section{Development of Hypotheses}

Previous studies have focused on working capital management as applied on several economic sectors but insurance organizations have different nature of work from other economic sectors and so the variables for working capital management,

Most of previous studies were applied to manufacturing sector As for Jakpar et al. (2017), Hingurala Arachchi et al. (2017), Amarjit Gill et al. (2010) and Sugeewa Kadithuwakka (2015), those studies measured working capital management by cash conversion cycle, inventory turnover account payable and account receivable and some of them in cement industry like chuke Nwude et al(2020) but this study was applied to insurance industry which has a different nature so this study selected the measurement of working capital by current ratio quick ratio and liquidity in line with this study. Gamlath and Rathiranee (2014) the study measured working capital management by current ratio, cash ratio and liquidity as applied to banks

As there are differences in the previous studies conclusions, the hypotheses of this study have been formulated indirectly

Hypothesis (1): there is relationship between working capital management and return on equity

$$
R O E=\beta_{0} \pm \beta_{1} C R \pm \beta_{2} Q R \pm \beta_{3} L+\varepsilon
$$

Where $\beta_{0}=0$

This hypothesis developed based on the most previous study but the difference in sub variables which used to measure the Woking capital management, the sub variables selected in this study according to the nature of insurance firms work as financial intermediate as the following sub variables which measured the working capital management in line with Muhammad Sial and Aqsa Chaudhry (2012) this study was selected working capital management as independent variable and profitability as dependent variable.

$1 / 1$ - There is relationship between current ratio and return on equity.

$1 / 2$ - There is relationship between quick ratio and return on equity.

$1 / 3-$ There is relationship between liquidity and return on equity.

Hypothesis (2) there is Relationship between working capital management and return on asset is a negative

$$
R O A=\beta_{0} \pm \beta_{1} C R \pm \beta_{2} Q R \pm \beta_{3} L+\varepsilon
$$

Where: $\beta_{0}=0$

On the contrary with this study Nadeem Iqbal et al (2014) the study found a negative significant relationship between net operating profitability on cash conversion cycle, average payment period, inventory turnover and average collection period, however in this study the variables selected based on nature of insurance industry as financial intermediate.

As for Chuke Nwude et al. (2020), the study found a significant relationship between working capital on (current 
assets to total revenue) while there is insignificant relationship between working capital on (total debt ratio / return on assets- total debt ratio / return on equity, inventory turnover) on ROE also receivable period has a positive impact on ROA on contrary of that account payable has a negative effect on ROA.

2/1-There is relationship between current ratio and the return on asset.

2/2-There is relationship between quick ratio and return on assets.

2/3-There relationship between liquidity and the return on assets.

Hypothesis (3)-There is relationship between working capital management and asset quality

Where: EA = Earning Assets; $\beta_{0}=0$

This hypothesis developed according to interact between the working capital management and asset quality with applying norms of the Egyptian Financial regulatory Authority regarding to its elements.

$3 / 1$-There is relationship between current ratio and the asset quality.

$3 / 2-$ There is relationship between quick ratio and asset quality.

$3 / 3$ - There is relationship between liquidity ratio and asset quality.

\section{The Research Objective and Methodology}

- In applying of the norms d by Egyptian Financial Regulatory Authority, there is a relationship between working capital management and asset quality in insurance industry so this study has tested the relationship between them, there are no previous studies published yet in this area in Egypt.

- To identify linkage between working capital management as short term decision on the firms profitability and asset quality.

Using descriptive and Structural equation modelling to identify the relationship between the dependent variables (return on equity - return on assets and asset quality) and independent variables (current ratio, quick ratio and liquidity)

\subsection{Population and Sample}

This study used structural equation model of insurance firms in Egypt, data extracted from the Financial Regulatory Authority reporting (balance sheets and income statements) during the period 1999-2019. The insurance market in Egypt contained (39) companies by the end of the year 2019 the applied sample consists of 19 firms that represent $49 \%$ from all companies working under Financial Regulatory Authority in Egypt.

\subsection{Development of Variables}

Asset quality (Earning Assets) was selected as a dependent variable because most of its elements are determined by Financial Regulatory Authority and some of them represent the working capital management.

4.2.1 In terms of Dependent variables

Profitability measured by

$\mathrm{ROA}=($ Revenue - Expenditures $) /$ Total Assets

Where ROA $=$ Return on Assets

$\mathrm{ROE}=($ Revenue - Expenditures $) /$ Equity

Where $\mathrm{ROE}=$ Return on equity

Asset quality $=$ Earning Assets / Total Assets

4.2.2 In terms of Independent variables

Working capital management

$$
\mathrm{CR}=\mathrm{CA} / \mathrm{CL}
$$

Where: $\mathrm{CR}=$ Current Ratio, $\mathrm{CA}=$ Current Assets, $\mathrm{CL}=$ Current Liabilities

$$
\mathrm{QR}=(\mathrm{CA}-\mathrm{Inv}) / \mathrm{CL}
$$

Where: Quick Ratio, Inv = inventory) 


$$
\mathrm{L}=\mathrm{C}-\mathrm{CL}
$$

Where: $\mathrm{L}=$ Liquidity, $\mathrm{C}=$ Cash

\section{Empirical Findings and Discussion}

\subsection{Hypothesises Testing}

Table 1. Outputs of descriptive statistics

\begin{tabular}{lllllll}
\hline Constructs & X1 & X2 & X3 & Y1 & Y2 & Y3 \\
\hline Mean & 1.102094 & 0.293178 & 0.089184 & 0.141387 & 0.031490 & 0.815257 \\
Median & 1.093078 & 0.132480 & 0.068289 & 0.139345 & 0.029635 & 0.824534 \\
Maximum & 1.439694 & 1.265079 & 0.312082 & 0.507055 & 0.094744 & 0.993822 \\
Minimum & 0.764558 & -0.508337 & -0.123388 & -0.240730 & -0.034713 & 0.553707 \\
Std. Dev. & 0.138661 & 0.313739 & 0.081366 & 0.147195 & 0.025771 & 0.095954 \\
Skewness & -0.042804 & 0.791249 & 0.752290 & 0.097829 & 0.103827 & -0.329693 \\
Kurtosis & 2.522519 & 2.577521 & 2.869768 & 2.924681 & 2.785590 & 2.644849 \\
Jarque-Bera & 3.912139 & 44.60132 & 37.91701 & 0.730745 & 1.481153 & 9.325316 \\
Probability & 0.141413 & $0.001^{* * *}$ & $0.001^{* * *}$ & 0.693938 & 0.476839 & $0.009441^{* *}$ \\
Observations & 399 & 399 & 399 & 399 & 399 & 399 \\
\hline
\end{tabular}

*** Probability at a level less than $(0.001) .{ }^{* *}$ Probability at a level less than $(0.01)$

As per Table 1, outputs the normality distribution of study independent variables (current ratio (x1), return on equity (Y1), and dependent variable return on assets) (Y2) by using the Jarque-Bera test at a probability level $(0.05)$. However, the study variables quick ratio (x2), liquidity(X3), and asset quality (Y3) are not normally distributed, since probability $\geq(0.05)$ Jarque-Bera statistic. The value of Pearson skewness coefficient is $\geq 1 \leq$ $(-1)$, due to table 1 outcome, that data is insignificantly skewed.

\subsection{The Test of Group Unit Root}

This study used Augmented Dickey-Fuller- Philips-Perrron and (Im, Pesaran and Shin W-stat) tests to ensure of mean and variance are invariant over time.

Table 2 . The test of Group unit root of working capital management on profitability and asset quality

\begin{tabular}{|c|c|c|c|c|}
\hline Method & Statistic & Prob.** & $\begin{array}{l}\text { Cross- } \\
\text { Sections }\end{array}$ & Obs \\
\hline \multicolumn{5}{|c|}{ Null: Unit root (assumes common unit root process) } \\
\hline Levin, Lin \& Chu t* & -12.8549 & $0.001 * * *$ & 6 & 2387 \\
\hline \multicolumn{5}{|c|}{ Null: Unit root (assumes individual unit root process) } \\
\hline Im, Pesaran and Shin W-stat & -16.0046 & $0.001 * * *$ & 6 & 2387 \\
\hline ADF - Fisher Chi-square & 261.087 & $0.001 * * *$ & 6 & 2387 \\
\hline PP - Fisher Chi-square & 286.640 & $0.001 * * *$ & 6 & 2388 \\
\hline
\end{tabular}

*** Probability t at alevel less than (0.001).

The Table 2 outcomes, concluded that stationary of the time series of return on equity $\left(\mathrm{y}_{1}\right)$, return on assets $\mathrm{y}_{2}$, asset quality $\mathrm{y}_{3}$, current ratio $\mathrm{x}_{1}$, quick ratio $\mathrm{x}_{2}$, and liquidity $\mathrm{x}_{3}$, at level $1 \sim(0)$ based on the constant level, through to the following criteria; used the above tests, probability $\geq(0.001)$.

\subsection{Statistical Co-Integrating Equation Model}

To measure the existence of long-run equilibrium relationships among non-stationary time series variables (return on equity $\mathrm{y}_{1}$, return on assets $\mathrm{y}_{2}$, asset quality $\mathrm{y}_{3}$,)) current ratio $\mathrm{x}_{1}$, quick ratio $\mathrm{x}_{2}$, and liquidity $\mathrm{x}_{3}$ ), the co-integration equation model was used as follows: 
Table 3. Cointegrating Model for variables

\begin{tabular}{lllll}
\hline Dependent & tau-statistic & Prob.* & z-statistic & Prob.* \\
\hline Y1 & -7.577884 & $0.001 * * *$ & -135.3143 & $0.001 * * *$ \\
Y2 & -8.686351 & $0.001 * * *$ & -127.1471 & $0.001 * * *$ \\
Y3 & -5.330029 & $0.0094 * *$ & -55.70295 & $0.0049 * *$ \\
X1 & -6.242228 & $0.001 * * *$ & -71.14870 & $0.001 * * *$ \\
X2 & -9.831197 & $0.001 * * *$ & -156.0248 & $0.001 * * *$ \\
X3 & -9.763499 & $0.001 * * *$ & -151.3127 & $0.001 * * *$ \\
\hline
\end{tabular}

*** Probability at a level less than (0.001).** Significant at a level less than (0.01).

As per table 3, it is a clear that there is long-term equilibrium relationships between dependent variables and independent variables during the study period, abased on the Tau-statistic, and Z-statistic, probability $\geq(0.01)$.

5.4 The Values of the Pearson Correlation Matrix

Table 4. Correlation matrix

\begin{tabular}{lllllll}
\hline Constructs & $\mathrm{Y} 1$ & $\mathrm{Y} 2$ & $\mathrm{Y} 3$ & $\mathrm{X} 1$ & $\mathrm{X} 2$ & $\mathrm{X} 3$ \\
\hline $\mathrm{Y} 1$ & 1 & & & & & \\
$\mathrm{Y} 2$ & $0.586^{* * * *}$ & 1 & & & & \\
$\mathrm{Y} 3$ & $0.627 * * *$ & $0.462 * * *$ & 1 & & & \\
$\mathrm{X} 1$ & $0.485 * * *$ & $0.413^{* * * *}$ & $0.567 * * *$ & 1 & & \\
$\mathrm{X} 2$ & $0.542 * * *$ & $0.416^{* * *}$ & $0.561 * * *$ & $0.534 * * *$ & 1 & \\
$\mathrm{X} 3$ & $0.602 * * *$ & $0.545^{* * *}$ & $0.620 * * *$ & $0.431 * * *$ & $0.469 * * *$ & 1 \\
\hline
\end{tabular}

*** Probability at a level less than (0.001).

Table 4, the outcomes indicate that there are significant positive linear relationships between $t$ return on equity (Y1), return on assets(Y2), and asset quality (y3) and the construct of independent variables (current ratio(x1), quick ratio (x2), and liquidity (x3), ) at a Significant level less than (0.001).

\subsection{Structural Equation Modelling (SEM)}

Structural equation modelling (SEM) set of methods and techniques were used to analyses the conceptual framework using AMOS23.One of these techniques, provides the most efficient estimation techniques, it includes a set of separate multiple regression equations estimated simultaneously where constructs could be represented by a summated scale, moreover, SEM clearly distinguishes between unobserved theoretical constructs and imperfect empirical measures and it is covariance-based rather than variance-based.

To evaluate the model fit the study used several indices tests like normed Chi - Square, goodness-of-fit index (GFI), and other tests will be shown in the following tables

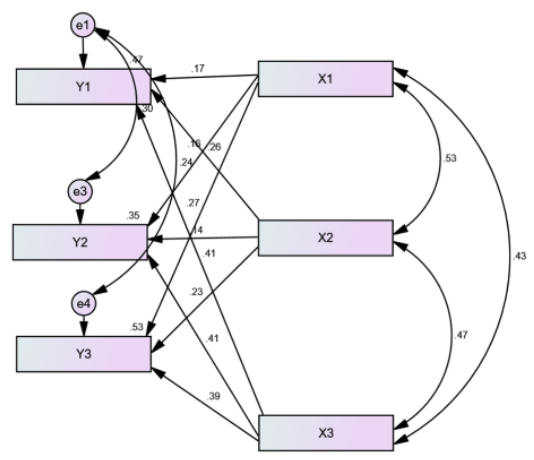

Figure 1. Structural equation modelling for testing the effect on construct of the variables (current ratio $\left(\mathrm{x}_{1}\right)$, quick ratio $\left(\mathrm{x}_{2}\right)$, and liquidity $\left(\mathrm{x}_{3}\right)$ on the construct of the dependent variables in terms of return on equity $(\mathrm{Y} 1$,) return on assets ( $\mathrm{Y} 2$, , and asset quality $\left(\mathrm{Y}_{3}\right)$ 
Table 5. Regression weights for testing the effect on construct of $\left(\mathrm{x}_{1}, \mathrm{x}_{2}\right.$, and $\left.\mathrm{x}_{3}\right)$ on the construct of $\left(\mathrm{Y}_{1}, \mathrm{Y}_{2}\right.$, and $\mathrm{Y}_{3}$ ) based on Maximum Likelihood Estimates

\begin{tabular}{|c|c|c|c|c|c|c|c|}
\hline Path & & & $\begin{array}{l}\text { Standardized } \\
\text { estimate }\end{array}$ & $\begin{array}{l}\text { Unstandardized } \\
\text { estimate }\end{array}$ & S.E. & C.R. & SIG. \\
\hline Y1 & $<---$ & $\mathrm{X} 1$ & .171 & .145 & .038 & 3.847 & $0.001 * * *$ \\
\hline Y2 & $<---$ & $\mathrm{X} 1$ & .163 & .157 & .047 & 3.308 & $0.001 * * *$ \\
\hline Y3 & $<---$ & $\mathrm{X} 1$ & .275 & .223 & .034 & 6.543 & $0.001 * * *$ \\
\hline Y1 & $<---$ & $\mathrm{X} 2$ & .261 & .224 & .039 & 5.740 & $0.001 * * *$ \\
\hline Y2 & $<---$ & $\mathrm{X} 2$ & .137 & .133 & .049 & 2.710 & $0.007 * *$ \\
\hline Y3 & $<--$ & $\mathrm{X} 2$ & .228 & .188 & .035 & 5.328 & $0.001 * * *$ \\
\hline Y1 & $<--$ & $\mathrm{X} 3$ & .408 & .398 & .042 & 9.584 & $0.001 * * *$ \\
\hline Y2 & $<---$ & $\mathrm{X} 3$ & .410 & .455 & .052 & 8.681 & $0.001 * * *$ \\
\hline Y3 & $<---$ & X3 & .395 & .369 & .038 & 9.827 & $0.001 * * *$ \\
\hline
\end{tabular}

Normed Chi-Square $=1.966$ RMR $=0.006$ GFI $=0.998 \quad$ AGFI $=0.966 \quad$ NFI $=0.998 \quad$ RFI $=0.972 \quad$ IFI $=0.999 \quad$ TLI $=0.986 \quad$ CFI $=0.999$ RMSEA $=0.049$

*** Probability at a level less than $(0.001) . * *$ Probability at a level less than $(0.01)$.

As per table (5), it is clear that There is a positive significant effect on construct of (current ratio(x1), quick ratio(x2), liquidity (x3)) on construct of return on equity (Y1), at a significant level less than $(0.001)$. the first hypothesis; the independent variables (Current Ratio $\left(\mathrm{x}_{1}\right)$, Quick Ratio $\left(\mathrm{x}_{2}\right)$, and Liquidity $\mathrm{x}_{3}$ ) have a significant effect on the dependent variables in terms of return on equity $\left(\mathrm{Y}_{1}\right)$, with regression model as the following:

$$
y_{1}=0.171 x_{1}+0.261 x_{2}+0.408 x_{3}
$$

The independent variables were accepted, Current Ratio X1, Quick Ratio X2, and Liquidity x3, in SEM explain (47.1\%) from all variation of dependent variable; Return on Equity $\mathrm{y} 1$, based on this result the rest percent are Independent Variables excluded or the random error in the regression model from regression model this result in line with Solabomi Ajibolade and Oboh Sankay (2013), the results show that there is a significant positive associated with debt ratio on profitability and size of the firm but negative relationship between debt ratios on working capital ratio . On the contrary of this result and in concur with, chuke Nwude et al. (2020), the findings indicate that there is a significant relationship between the working capital with the current assets to total revenue but insignificant relationship with the (total debt ratio / return on asset, total debt ratio / return on equity, inventory conversion period) on ROE also receivable period has a positive impact on ROA on contrary of that account pay able has a negative effect on ROA. But this study on the contrary Osama EL-Ansary and Heba Al-Gazzar (2020), the study concluded that net working capital has non- leaner impact on the return on asset but has a negative effect on return on equity

On the contrary with this study Muhammad S. Sial and Aqsa Chaudhry (2012), the findings indicate that there is a negative relationship between working capital management on profitability, beside that there are negatively statistical relationship between size of firm and debt ratio on profitability. However, in other previous studies using different variables for measuring working capital management for example

There is a positive significant effect on construct of the independent variables (current ratio $\left(\mathrm{x}_{1}\right)$, quick ratio $\left(\mathrm{x}_{2}\right)$, and liquidity $\left(\mathrm{x}_{3}\right)$ on the construct of the dependent variables (return on assets $\left(\mathrm{Y}_{2}\right)$, at a probablity level less than $(0.01)$. the second hypothesis; the independent variables in terms of current ratio $\left(\mathrm{x}_{1}\right)$, quick ratio $\mathrm{x}_{2}$, and liquidity $\left(\mathrm{x}_{3}\right)$ have a significant effect on the dependent variables in terms of return on asset $\left(\mathrm{Y}_{2}\right)$, with regression model as the following:

$$
y_{2}=0.163 x_{1}+0.137 x_{2}+0.410 x_{3}
$$

The independent variables were accepted, current ratio $x_{1}$, quick ratio $x_{2}$,and liquidity $x_{3}$, in SEM explain (34.8\% ) from all variation of dependent variable;(return on assets $\mathrm{Y}_{2}$, based on this result the rest percent are Independent Variables excluded from regression model or the random error in the regression model, this study in line with Seyed Fahim and Meysam Kaviani (2015), the study analyzed relationship between working capital management and profitability, findings indicate that there is significant relationship between the current ratio on return on assets, also there are significant relationships between cash conversion cycle, quick ratio and ( net 
working capital / total assets )on return on assets. And in line with Adamu Yahaya and Hussaini Bala (2015), which empirical proved positive significant relationship between quick ratio and current ration on profitability but there is a negative relationship between liquidity on profitability of deposit Money Banks in Nigeria. Also Gamlath, G R M \& Rathiranee, Y (2014) the study found a positive insignificant relationship between current ratio, loans to deposit ratio, cash ratio on net profit margin and return on assets but negatively insignificant relationship between current ratio, loans to deposit ratio, cash ratio on return on capital employed

On the contrary of this result MarcDeloof (2003), this study investigates the relationship working capital management on profitability the findings indicate that there is a negative relationship between the profitability with number of days account payable and number of days inventories as working capital sub variables. Also on the contrary Muhammad S. Sial and Aqsa Chaudhry (2012), the study found a negative associated with working capital management on profitability, Also that found a negative significant relationship between size of the firm and debt ratio on profitability, however, this study in line with Ahmed SU, \& et al 2007finding indicates there is a positive significant relationship between working capital management measured by (cash conversion cycle,current asset / total asset and current asset to current liability) on profitability in Bangladesh textile sector.

There is a positive significant effect on construct of the variables current ratio $\left(\mathrm{x}_{1}\right)$, quick ratio $\left(\mathrm{x}_{2}\right)$, and liquidity $\left(\mathrm{x}_{3}\right)$ on the construct of the $t$ variables asset quality $\left(\mathrm{Y}_{3}\right)$, at a significant level less than $(0.001)$. This validates the third research hypothesis; the independent variables current ratio $\mathrm{x}_{1}$, quick ratio $\left(\mathrm{x}_{2}\right)$, and liquidity $\left(\mathrm{x}_{3}\right)$ have a significant effect on the dependent variables asset quality $\left(\mathrm{Y}_{3}\right)$, with regression model as the following:

$$
y_{3}=0.275 x_{1}+0.228 x_{2}+0.395 x_{3}
$$

The independent variables were accepted, (current ratio $\left(\mathrm{x}_{1}\right)$, quick ratio $\left(\mathrm{x}_{2}\right)$,and liquidity $\left(\mathrm{x}_{3}\right)$, in SEM explain $(52.9 \%)$ of all variation of dependent variable; asset quality $\left(\mathrm{Y}_{3}\right)$, based on this result the rest percent are Independent Variables excluded from regression model or the random error in the regression model or other The fit test shows the goodness of fit structural equation modelling and its ability to test the effect on construct of independent variables (current ratio $\left(\mathrm{x}_{1}\right)$, quick ratio $\left(\mathrm{x}_{2}\right)$, and liquidity $\left(\mathrm{x}_{3}\right)$ on the construct of the dependent variables (return on equity $\left(\mathrm{Y}_{1}\right)$, return on assets $\left(\mathrm{Y}_{2}\right)$, and asset quality $\left(\mathrm{Y}_{3}\right)$ ).

Based on two tests (RMR) Root Mean Square Residual and (RMSEA) Root Mean Square Residual Approximation less than (0.08), this result shows a close fit of applied model.

To test the goodness of fit of the model were used several indicators, some of them indicate that are acceptable limits and other greater than cut-off values, especially GFI, AGFI, NFI, RFI, IFI.TLI, and CFI close to one and Normed Chi-Square with cut-off values less than (5).

\section{Conclusion}

To identify relationship between working capital management on ROE, ROA and Asset Quality in Egyptian insurance industry the study sample is $49 \%$ of total insurance market which working under Egyptian Financial Regulatory Authority over the period 1999- 2019 using a structural equation modelling, the findings on the contrary of most previous literature review

1. There is a positive significant effect on construct of the independent variables (current ratio $\left(\mathrm{x}_{1}\right)$, quick ratio $\left(\mathrm{x}_{2}\right)$, and liquidity $\left.\left(\mathrm{x}_{3}\right)\right)$ on construct of Return on Equity $\left(\mathrm{Y}_{1}\right)$ as the first dependent variable, probability level less than (0.001). This validates hypothesis (1); the independent variables (current ratio $\left(\mathrm{x}_{1}\right)$ quick ratio, $\left(\mathrm{x}_{2}\right)$, and liquidity $\left(\mathrm{x}_{3}\right)$ have a significant effect on the dependent variables in terms of return on equity $\left(\mathrm{Y}_{1}\right)$.

2. There is a positive significant effect on construct of the independent variables (current ratio $\left(\mathrm{x}_{1}\right)$, quick ratio $\left(\mathrm{x}_{2}\right)$ and liquidity $\left(\mathrm{x}_{3}\right)$ on construct of return on assets $\left(\mathrm{Y}_{2}\right)$ as the second dependent variable, probability level less than (0.01). This validates hypothesis (2); the independent variables (current ratio $\left(\mathrm{x}_{1}\right)$, quick ratio $\left(\mathrm{x}_{2}\right)$, and liquidity $\left.\left(\mathrm{x}_{3}\right)\right)$ have significant effect on the dependent variables return on assets $\left(\mathrm{Y}_{2}\right)$.

3. There is a positive significant effect on construct of the independent variables in terms of current ratio $\left(\mathrm{x}_{1}\right)$, quick ratio $\left(\mathrm{x}_{2}\right)$, and liquidity $\left(\mathrm{x}_{3}\right)$ on the construct of the variables, asset quality $\left(\mathrm{Y}_{3}\right)$, probability level less than (0.001). This validates hypothesis (3); the independent variables (current ratio( $\left.\mathrm{x}_{1}\right)$, quick ratio $\left(\mathrm{x}_{2}\right)$, and liquidity $\left(\mathrm{x}_{3}\right)$ ) have significant effect on asset quality $\left(\mathrm{Y}_{3}\right)$. 


\section{References}

Adamu, Y., \& Hussaini, B. (2015). Working Capital Management and Financial Performance of Deposit Money Banks in Nigeria. Research Journal of Finance and Accounting, 6(16). https://doi.org/10.7176/RJFA

Ahmed, S. U. et al. (2007). Impact of Working Capital Management on Profitability: A Study on Textile Companies of Bangladesh. Journal of Business \& Financial Affairs, 6(4). http://dx.doi.org/10.4172/2167-0234.1000292

Amarjit, G. et al. (2010). The Relationship between Working Capital Management and Profitability: Evidence from the United States. Business and Economics Journal, 10.

Amr, A. M. (2018). The impact of working capital management on firms' performance and value: evidence from Egypt. Journal of Asset Management, 19. https://doi.org/10.1057/s41260-018-0081-z

André, L. D. S. G., \& Valcemiro, N. (2010). Working capital, profitability, liquidity and solvency of healthcare insurance companies. Brazilian Business Review, 2. http://dx.doi.org/10.15728/bbr.2010.7.2.3

Ashok, K. P. (2014). Understanding the Working Capital Financing Strategy (A Case Study of Lupine Limited). Journal of Management Research and Analysis, 1(1). https://ssrn.com/abstract=2512692

Chuke Nwude et al. (2020). the relationship between working capital management and corporate returns of cement industry of emerging market. International Journal of Finance and Economic, 25(3). https://doi.org/10.1002/ijfe.1959

Daisuke, T. (2018). Do Working Capital Strategies Matter? Evidence from Small Business Data in Japan. Asia-Pacific Journal of Financial Studies, 47. https://doi.org/10.1111/ajfs.12239.

Elangkumaran, P., \& Nimalathasan, B. (2016). The Impact of Working Capital Management on Corporate Profitability: Evidence from Listed Manufacturing Company of the Colombo Stock Exchange in Sri Lanka: Accounting Governance \& Corporate Sustainability: Proceedings of the 2nd International Conference for Accounting Researchers and Educators -2016 Conference (pp-30), University of Kelaniya. https://ssrn.com/abstract=3132932.

Gamlath, G. R. M., \& Rathiranee, Y. (2014). Effects of Working Capital Management and Profitability: Evidence from Listed Commercial Banks in Sri Lanka. Journal of Business Studies.

Hingurala Arachchi et al. (2017). The Impact of Working Capital Management on Firm Value: Evidence from a Frontier Market, Asian Journal of Finance \& Accounting, 9(2). https://doi.org/10.5296/ajfa.v9i2.12449

Iluta, A., \& Svetlana, I. (2012). The Relationship between Working Capital Management and Profitability: A Latvian Case. http://dx.doi.org/10.2139/ssrn.2128447

Jakpar et al. (2017). Working Capital Management and Profitability: Evidence from Manufacturing Sector in Malaysia. Journal of Business and Financial Affairs, 6(2). https://doi.org/10.4172/2167-0234.1000255

Jamal, Z. (2011). Impact of Working Capital Management and Capital Structure on Profitability of Automobile Firms in Pakistan. https://dx.doi.org/10.2139/ssrn.1663354

Joana et al (2011). The Impact of Working Capital Management upon Companies' Profitability: Evidence from European Companies. https://dx.doi.org/10.2139/ssrn.2165210

Julius Enqvist et al. (2013). The Impactof Working Capital Management on Firm Profitability in Different Business Cycle: Evidence from Finland. https://dx.doi.org/10.2139/ssrn.17948

Mansoori, D. E., \& Muhammad, D. J. (2012). The effect of working capital management on firm's profitability: Evidence from Singapore. Interdisciplinary Journal of Contemporary Research in Business, 4(5), 472-486.

Marc, D. (2003). Does the working capital management effect profitability of Belgian. Journal of Business Finance \& Accounting, 30(3) \& (4). https://doi.org/10.1111/1468-5957.00008

Mathew et al. (2010). Net Operating working Capital Behaviour: A First Look. Financial Management, 39(2). https://doi.org/10.1111/j.1755-053X.2010.01092.x

Mihir, D., \& Rani, H. (2000). A Liquidity -Profitability Trade-off Model for Working Capital Management. https://dx.doi.org/10.2139/ssrn.1408722

Muhammad, S. S., \& Aqsa, C. (2012). Relationship between Working Capital Management and Firm Profitability: Manufacturing Sector of Pakistan. https://dx.doi.org/10.2139/ssrn.2105638 
Muhammadet al. (2021). Corporate Governance, Working Capital Management and firm performance: some new insight from agency theory. Managerial Decision Economic, 42(6). https://doi.org/10.1002/mde.3466.

Nadeem Iqbal et al. (2014). The Relationship between Working Capital Management and Profitability: Evidence from Pakistan. International Letters of Social and Humanistic Sciences, 20, 14-25. https://doi.org/10.18052/www.scipress.com/ILSHS.20.14

Nobanee, H., \& Haddad, A. E. (2014). Working Capital Management and Corporate Profitability of Japanese Firms. The Empirical Economics Letters, 13(1).

Osama, E. A., \& Heba, A. G. (2020). Working capital and financial performance in MENA region. Journal of Humanities and Applied Social Sciences. http://dx.doi.org/10.1108/JHASS-02-2020-0036

Pedro, G, T., \& Pedro, M. S. (2007). Effect of working capital management on SMEs profitability. International Journal of Managerial Finance, 3(2). https://doi.org/10.1108/17439130710738718

Rathiranee, Y., \& Sangeetha, T. (2014). Working Capital Management and its Impact on Firms' Financial Performance: An Analysis of Trading Firms. Presentation in the International Conference at Rajarata University, Sri Lanka.

Ratnam, V. (2019). Efficiency of Working Capital Management and Firm Value: Evidence from Chinese Listed Firms. International Journal of Financial Research, 10(6). https://doi.org/10.5430/ijfr.v10n6p133

Ratnam, V., \& Sunitha, V. (2017). Working Capital Management and Corporate Performance: Evidence from Sri Lankan Listed Manufacturing Firms. International Journal of Accounting and Financial Reporting, 7(2). https://doi.org/10.5296/ijafr.v7i2.12453

Rehana, I. (2017). Working Capital - An Effective Business Management Tool, International Journal of Humanities and Social Science Invention, 6 (3). https://dx.doi.org/10.2139/ssrn.234580

Robert et al. (2013). Working Capital Management and Shareholders' Wealth. Review of Finance, 17(5). http://dx.doi.org/10.1093/rof/rfs043.

Samuel, K. A., \& Benjamin, Y. (2011). Working Capital Management and Profitability of Banks in Ghana. British Journal of Economics, Finance and Management Sciences, 2(2).

Sara et al. (2020). Effects of working capital management on firms' profitability: evidence from cheeseproducing companies. https://doi.org/10.1002/agr.21666

Seyed, R. S. F., \& Meysam, K. (2015). Providing a New Model for Assessment of Working Capital Management: Evidence from Tehran Stock Exchange. International Journal of Accounting and Financial Reporting, 5(1). http://dx.doi.org/10.5296/ijafr.v5i1.7284

Solabomi, O. A., \& Oboh, C. S. (2013). Working Capital Management and Financing Decision: Synergetic Effect on Corporate Profitability. International Journal of Management Economics and Social Sciences, 2(4). https://dx.doi.org/10.2139/ssrn.2367990

Sonia et al. (2010). working capital management in SMEs. Journal of Accounting and Finance, 50. https://doi.org/10.1111/j.1467-629X.2009.00331.x.

Thomas, K., \& Rosca, S. A. (2013). Empirical Analysis of Working Capital Management and its Impact on the Profitability of Listed Manufacturing Firms in Ghana. Research Journal of Finance and Accounting, 4(1).

Vinay, K. (2015). An Analysis of Working Capital Management in Select Construction Companies. Journal of Commerce \& Management Thought, 6-1. http://dx.doi.org/10.5958/0976-478x.2015.00001.4

Yuli, A. (2018). The Effect of Working Capital Management on Profitability in Manufacturing Company Listed in Indonesia Stock Exchange. The Accounting Journal of Binaniaga, 3(1). http://dx.doi.org/10.33062/ajb.v3i1.173.

\section{Copyrights}

Copyright for this article is retained by the author(s), with first publication rights granted to the journal.

This is an open-access article distributed under the terms and conditions of the Creative Commons Attribution license (http://creativecommons.org/licenses/by/4.0/). 